\title{
Internship Program in Education: Effectiveness, Problems and Prospects
}

\author{
Dr. Saleha Parveen \\ Associate Professor, Department of Curriculum \& Special Education, \\ Faculty of Education, University of Sindh, Sindh, Pakistan \\ Email: dr_saleha_parveen@yahoo.com
}

Nida Mirza

Lecturer, Faculty of Education, University of Sindh, Elsa Kazi Campus, Hyderabad, Pakistan

Accepted: January 26, 2012 Published: March 3, 2012

Doi:10.5296/ijld.v2i1.1471 URL: http://dx.doi.org/10.5296/ijld.v2i1.1471

\begin{abstract}
Internship program in Teacher Education is of great significance because it ensures the professional preparation of prospective teachers. It provides them a practical opportunity to develop true understanding of the teaching profession and future prospects of working conditions in that profession. This study looks at issues and challenges that the prospective teachers experience during internship program. The study also deals with the perception and experience of the principals of cooperative schools involved in the internship program.

Research approach for this study was both quantitative and qualitative. Population consisted of all student-teachers of B.Ed at Faculty of Education and principals of cooperative schools where students go for internship program. The 80 student-teachers and 05 principals of collaborative schools were selected as sample. Data was collected through three-point likert scale and in-depth interviews. The findings show that student-teachers view internship program as a real opportunity to refine and improve their teaching skills in actual school setting. The results of the in-depth interviews with the principals reveal that internship program is of crucial importance and it has positive impact on the performance of student-teachers.
\end{abstract}




\section{Macrothink Institute ${ }^{\mathrm{TM}}$

\section{Theoretical and Conceptual Frame Work of the Study}

An internship is a unique educational program that aims to integrate study with planned and performance related experience. It is usually designed for the benefits of young unemployed graduates and post graduates all over the world who have completed fourteen to sixteen years of education. The major purpose of the Internship program is to develop and strengthen student's skills and to prepare them for the profession. Many Internship Programs aims to provide financial support to fresh candidates and also to keep them engaged and interested in acquiring further knowledge related to the profession they want to join in future.

The Internship program is beneficial for both fresh candidates and government organizations. It provides an opportunity to the fresh candidates to experience working conditions and requirement of today's professional business environment. Hence, it can be said that it provides the student with a greater understanding of professional demands and qualification. It permits them to understand the connection between theory and practice, thus it enhance the student's knowledge of his potential to reach the goals set for various professions. Therefore, the internship program is of great significance because it ensures the professional preparation of students in various ways such as understanding of the target profession and future prospects of working conditions in that profession. A carefully planned internship program may serve the following functions.

- Understanding of the target profession and future prospects of working conditions.

- Can provide valuable exposure on the job

- Develop professional skills and attitudes

- Establish useful contacts with people working in the same profession.

The organizations and institutions that allow internship program benefit by having a dedicated and excited intern as a part of their team. Thus, it can be said that the internship work in two ways and are beneficial for both the intern and the organizations.

Primarily two types of Internship programs are offered by the institutions, one is work experience internship and another is dissertation internship. The former program is offered in the second or third year of the Education. The placement can be from two months to one year. In this period the student is supposed to use the things he / she has learned in institution and put these in practice, in this way they get work experience in their related fields. Dissertation internship program is offered to those students who are in the last year of their education. In this type of internship a student does research for a particular company. The company / organization can have something that they feel like they need to improve, or the students can choose a topic with in the company themselves. At the end a report of research findings is prepared and presented. All over the world like UK, USA, Germany, France, Nether land, Denmark, such types of internship programs are offered to the students. Both paid and unpaid programs provide work experience, job training and confidence to the students.

In Pakistan, internship programs to also offered to the students by different institutions/organizations At national level the National Internship program is designed for the benefit of young graduates who have completed sixteen year education from recognized universities and degree awarding institutions. This scheme is intended to provide financial relief to the fresh graduates and also give them work experience. In the field of education it is 
comparatively a new concept. In this regard National Education Policy (NEP), 2009 state that: "Approaches shall be found to provide students with a window to the world of work. This could involve short assignments with the local enterprises and institutions or "job shadowing" approaches to familiarize students with the work environment".(NEP, 2009)

Teacher education is one of the important branches of education because the development of our future generation depends on the quality of teachers. But in spite of many efforts at governmental level it remains a neglected sector. According to National Education Policy (NEP, 2009). "Reforms is required in all areas: pre-service training and standardization, of qualifications; teacher remuneration, carrier progression and status; and governance and management of the teaching work force". (NEP, 2009)

The University of Sindh since its inception has given higher priority to teacher education and producing quality teachers and other professionals to meet the needs of schools and society. To maintain the quality education and to give the real school/classroom experiences to student-teachers, Faculty of Education, University of Sindh started internship program in 2007-08 as a compulsory component of B.Ed degree. In the last semester each student-teachers have to go to the collaborative schools of Faculty of Education for Internship, where they practice the lessons of their specialized fields and also observe school environment, administration, record keeping, timetable arrangements and other component of school program. After successful completion of the program, they receive internship certificate. Therefore, the aim of writing this article is to evaluate the effectiveness of internship program of Faculty of Education, University of Sindh and also find out problems and hurdles facing by student-teachers during the program. At the end suggestions will be made on the basis of research outcome for the improvement of this program in Faculty of Education, University of Sindh in particular and in other teacher training institutions in general.

\section{Objectives Of the Study}

This study is specifically designed to:
a) Evaluate the effectiveness of internship program being started at Faculty of Education, University of Sindh in 2007-08.
b) Identify the problems and challenges that emerged during the internship program.
c) Suggest the possible measures for the improvement of internship program educational institutions who offers internship program to fresh teachers. specifically in Faculty of Education, University of Sindh and generally in all

\section{Research Questions}

Q. 1. What is the contribution that internship program can make in improving teaching skills and practices of prospective teachers?

Q. 2. How do student-teachers and their concerned supervisors perceive internship program?

\section{Research Design}

This study has been designed in both quantitative and qualitative paradigm. This research study is descriptive survey type in nature. The descriptive survey is selected because the primary 
purpose of this study is to determine the nature, effectiveness and weaknesses of internship program offered to student- teachers at Faculty of Education. After intensive review of related literature, two research tools were designed for collecting the data.

Tool \# 1: Three point likert scale with agree (A), disagree (DA), and undecided (UD) options was developed. The scale has four sections with 22 items in all. Through the tool data was collected from the students of B.Ed program. The sample population from which data collected was comprised of 80 students (40 students per year) of the year 2008 and 2009. All participants were asked to pointed out the problems and to make recommendations and modifications for improvement of Internship program by marking (A), (DA) and (UD) on Likert scale.

Tool\# 2: Within the context of qualitative paradigm an interview schedule was developed having 06 open ended questions, and it was administered to the principals of collaborative schools (05 schools) of Faculty of Education, University of Sindh.

Both tools were properly tested in order to confirm their validity and reliability. The data collected through questionnaire was analyzed by using descriptive statistical procedure. The results are given in graphic form. The interview is analyzed qualitatively. Drawing on a qualitative ethnographic method, the researcher analyzed descriptive information and used categorical aggregation to find emerging themes and develop interpretations (Creswell, 1998).

All recorded information from interviews and surveys was counted, reviewed several times, and coded to formulate outcomes and themes. On the basis of data analysis, findings were highlighted and suggestions were made for the improvement of internship program.

\section{Analysis of Data}

Analysis of data collected through research tool \# 01 (Likert Scale)

\section{TABLE \# 01}

\section{Showing the views about "Effectiveness and Usefulness of Internship Program"}

\begin{tabular}{|c|c|c|c|c|c|c|c|}
\hline S.\# & $\begin{array}{l}\text { The internship was } \\
\text { effective and useful } \\
\text { because it provided you } \\
\text { an opportunity to }\end{array}$ & $\begin{array}{l}\text { Agree } \\
\mathrm{n}=\mathbf{8 0}\end{array}$ & $\%$ & $\begin{array}{l}\text { Disagr } \\
\text { ee } \\
\mathbf{n}=\mathbf{8 0}\end{array}$ & $\%$ & $\begin{array}{l}\text { Undeci } \\
\text { ded } \\
\mathbf{n}=\mathbf{8 0}\end{array}$ & $\%$ \\
\hline 1. & $\begin{array}{l}\text { develop a true } \\
\text { understanding of the } \\
\text { complex nature of } \\
\text { teaching process. }\end{array}$ & 70 & 88 & 03 & 4 & 07 & 9 \\
\hline 2. & $\begin{array}{l}\text { integrate theory with } \\
\text { practice. }\end{array}$ & 52 & 65 & 12 & 15 & 16 & 20 \\
\hline 3. & $\begin{array}{l}\text { plan and deliver lessons } \\
\text { in various disciplines. }\end{array}$ & 55 & 69 & 17 & 21 & 08 & 10 \\
\hline
\end{tabular}




\begin{tabular}{|l|l|l|l|l|l|l|l|}
\hline \hline 4. & $\begin{array}{l}\text { reflect critically on your } \\
\text { teaching style and } \\
\text { practice. }\end{array}$ & $\mathbf{5 5}$ & $\mathbf{6 9}$ & $\mathbf{1 8}$ & $\mathbf{2 3}$ & $\mathbf{0 7}$ & $\mathbf{9}$ \\
\hline $\mathbf{5 .}$ & $\begin{array}{l}\text { refine and improve your } \\
\text { teaching methodology } \\
\text { and techniques. }\end{array}$ & $\mathbf{5 6}$ & $\mathbf{7 0}$ & $\mathbf{1 1}$ & $\mathbf{1 4}$ & $\mathbf{1 3}$ & $\mathbf{1 6}$ \\
\hline $\mathbf{6 .}$ & $\begin{array}{l}\text { understand the role and } \\
\text { responsibility of a } \\
\text { teacher. }\end{array}$ & $\mathbf{6 4}$ & $\mathbf{8 0}$ & $\mathbf{0 4}$ & $\mathbf{5}$ & $\mathbf{1 2}$ & $\mathbf{1 5}$ \\
\hline
\end{tabular}

$\square A=$ Agree $\square B=$ Disagree $\square C=$ Undecided

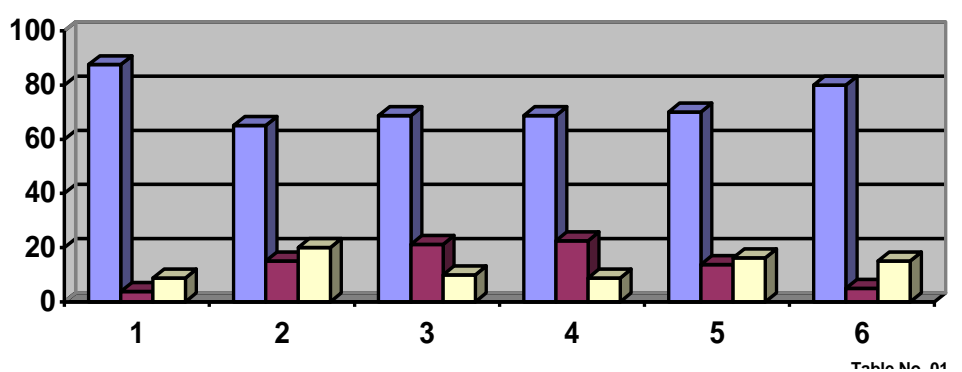

As indicated in table \# 01, that $88 \%$ participants agreed that internship program, develop a true understanding of the complex nature of teaching process, $65 \%$ were opined that this program integrate theory with practice. Moreover $69 \%$ stated that this program was effective and useful because it provided an opportunity to plan, deliver lessons in various disciplines and gave opportunity to critically analyze different teaching styles. $70 \%$ teacher-students agreed that through this program their teaching styles, methodologies and techniques were refined and improved, but $14 \%$ disagreed with this statement. $80 \%$ participants agreed that internship program gave them an opportunity to understand the role and responsibility of teacher very clearly.

TABLE \# 02

Showing views about "Internship Program that Improved Teaching Skills by Enhancing Different Abilities of Students"

\begin{tabular}{|l|l|l|l|l|l|l|l|}
\hline Sr. \# & $\begin{array}{l}\text { Internship } \\
\text { program } \\
\text { improved your } \\
\text { teaching skills by } \\
\text { enhancing your } \\
\text { ability in }\end{array}$ & $\begin{array}{l}\text { Agree } \\
\mathbf{n = 8 0}\end{array}$ & $\begin{array}{l}\text { Disagre } \\
\text { e } \\
\mathbf{n = 8 0}\end{array}$ & $\begin{array}{l}\text { Undecid } \\
\text { ed } \\
\mathbf{n}=\mathbf{8 0}\end{array}$ & \\
\hline 1. & $\begin{array}{l}\text { interacting and } \\
\text { working } \\
\text { students. }\end{array}$ & $\mathbf{5 8}$ & $\mathbf{7 3}$ & $\mathbf{1 2}$ & $\mathbf{1 5}$ & $\mathbf{1 0}$ & $\mathbf{1 3}$ \\
\hline
\end{tabular}




\begin{tabular}{|l|l|l|l|l|l|l|l|}
\hline \hline 2. & $\begin{array}{l}\text { designing and } \\
\text { implementing } \\
\text { lessons. }\end{array}$ & $\mathbf{4 7}$ & $\mathbf{5 9}$ & $\mathbf{1 3}$ & $\mathbf{1 6}$ & $\mathbf{2 0}$ & $\mathbf{2 5}$ \\
\hline $\mathbf{3 .}$ & time management. & $\mathbf{5 6}$ & $\mathbf{7 0}$ & $\mathbf{1 7}$ & $\mathbf{2 1}$ & $\mathbf{1 8}$ & $\mathbf{9}$ \\
\hline $\mathbf{4 .}$ & $\begin{array}{l}\text { classroom } \\
\text { management. }\end{array}$ & $\mathbf{5 8}$ & $\mathbf{7 3}$ & $\mathbf{1 9}$ & $\mathbf{2 4}$ & $\mathbf{0 3}$ & $\mathbf{4}$ \\
\hline $\mathbf{5 .}$ & peer observation. & $\mathbf{4 7}$ & $\mathbf{5 9}$ & $\mathbf{1 8}$ & $\mathbf{2 3}$ & $\mathbf{1 5}$ & $\mathbf{1 9}$ \\
\hline $\mathbf{6 .}$ & $\begin{array}{l}\text { designing teaching } \\
\text { aids and material. }\end{array}$ & $\mathbf{5 2}$ & $\mathbf{6 5}$ & $\mathbf{1 9}$ & $\mathbf{2 4}$ & $\mathbf{0 9}$ & $\mathbf{1 1}$ \\
\hline
\end{tabular}

\section{$\square A=$ Agree $\square B=$ Disagree $\square C=$ Undecided}

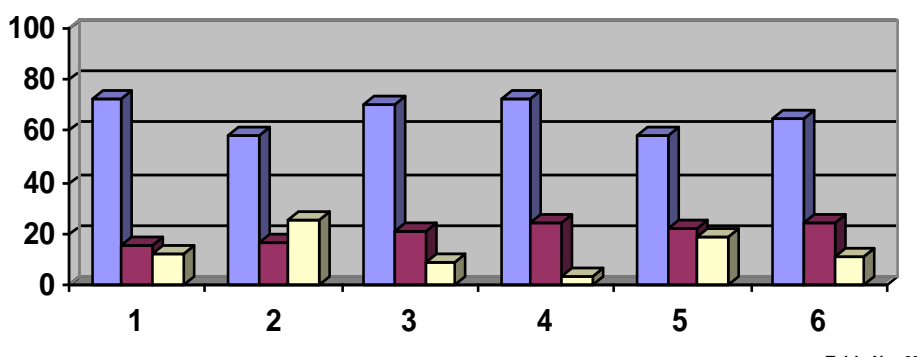

Table \# 02 shows that $73 \%$ student-teachers agreed that this program improved their teaching skills by enhancing their ability in interacting and working with students. $15 \%$ were disagreed with the statement. However, 59\% stated that internship program enhanced their ability in designing and implementing lessons and peer observation. $70 \%$ and $73 \%$ respectively were of the opinion that after completing this program their ability of time and classroom management were enhanced. $65 \%$ respondents said that this program improved their ability to design and use A.V aids in a more effective and better way.

TABLE \# 03

Showing the views about "The Role Played by Concerned Departments of Faculty of Education, S.U to make Internship Program Useful for Internees"

\begin{tabular}{|c|c|c|c|c|c|c|c|}
\hline Sr. \# & $\begin{array}{l}\text { Your concerned department } \\
\text { played a key role to make } \\
\text { internship useful for you by: }\end{array}$ & $\begin{array}{l}\text { Agree } \\
\mathbf{n}=\mathbf{8 0}\end{array}$ & $\%$ & $\begin{array}{l}\text { Disagr } \\
\text { ee } \\
\mathbf{n}=\mathbf{8 0}\end{array}$ & $\%$ & $\begin{array}{l}\text { Undecid } \\
\text { ed } \\
\mathbf{n}=\mathbf{8 0}\end{array}$ & $\%$ \\
\hline 1. & $\begin{array}{l}\text { providing you required help and } \\
\text { support. }\end{array}$ & 59 & 74 & 11 & 14 & 10 & 13 \\
\hline 2. & $\begin{array}{l}\text { planning, organizing and managing } \\
\text { internship program. }\end{array}$ & 50 & 63 & 20 & 25 & 10 & 13 \\
\hline 3. & $\begin{array}{l}\text { providing you clear guidance about } \\
\text { your supervisors and school of } \\
\text { internship. }\end{array}$ & 57 & 71 & 20 & 25 & 13 & 4 \\
\hline
\end{tabular}


4. $\quad$ maintaining close communication and link between students and concerned school supervisors. 2012, Vol. 2, No. 1

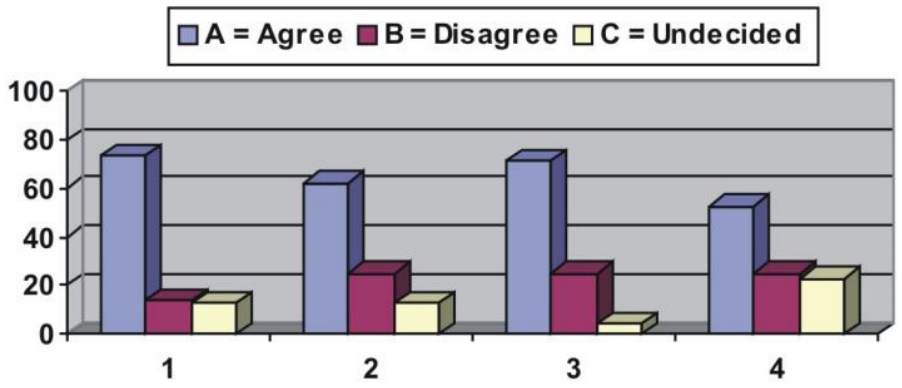

Table \# 03 indicated that $74 \%$ respondents agreed with the statement that their concerned departments played a key role to make internship useful for us by providing required help and support. However, $14 \%$ were disagreed with this statement. $63 \%$ participants agreed that the concerned department make this program useful by planning, organizing and managing it properly. However, 25\% student-teachers said that their concerned departments do not provide them clear guidance about school supervisors and school environment. They also pointed out that the department does not maintain close communication and link between students and concerned school supervisors.

TABLE \# 04

Showing the views about "The Role Played by Concerned Supervisors in Developing Teaching Skills for Internees"

\begin{tabular}{|c|c|c|c|c|c|c|c|}
\hline $\begin{array}{l}\text { Sr. } \\
\#\end{array}$ & $\begin{array}{l}\text { The concerned supervisor } \\
\text { played an important role in } \\
\text { enhancing your teaching skills } \\
\text { by }\end{array}$ & $\begin{array}{l}\text { Agre } \\
\mathrm{e} \\
\mathrm{n}= \\
80\end{array}$ & $\%$ & $\begin{array}{l}\text { Disagr } \\
\text { ee } \\
\mathrm{n}=\mathbf{8 0}\end{array}$ & $\%$ & $\begin{array}{l}\text { Undecid } \\
\text { ed } \\
\mathrm{n}=\mathbf{8 0}\end{array}$ & $\%$ \\
\hline 1. & $\begin{array}{l}\text { allowing you freedom to practice } \\
\text { what you had learnt from Method } \\
\text { teacher. }\end{array}$ & 58 & 73 & 10 & 13 & 12 & 15 \\
\hline 2. & $\begin{array}{l}\text { providing you written comments } \\
\text { on your lesson. }\end{array}$ & 49 & 61 & 18 & 23 & 13 & 16 \\
\hline 3. & observing your lessons regularly. & 65 & 81 & 10 & 13 & 05 & 6 \\
\hline 4. & $\begin{array}{l}\text { providing you timely and } \\
\text { suggestive feedback. }\end{array}$ & 67 & 84 & 08 & 10 & 07 & 6 \\
\hline 5. & $\begin{array}{l}\text { providing you opportunity for } \\
\text { collaborative planning with them. }\end{array}$ & 45 & 56 & 30 & 38 & 05 & 6 \\
\hline 6. & $\begin{array}{l}\text { demonstrating model lessons for } \\
\text { you. }\end{array}$ & 35 & 44 & 45 & 56 & 00 & $\begin{array}{l}0.0 \\
0\end{array}$ \\
\hline
\end{tabular}




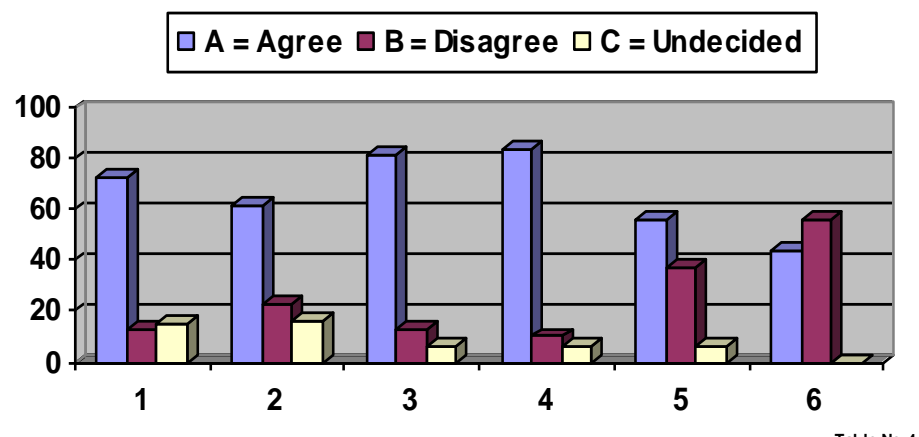

As indicated in table \# 04, 73\% student-teachers were of the opinion that the concerned supervisors played an important role in enhancing their teaching skills by allowing them freedom to practice what they had learned from method teachers. $81 \%$ stated that the concerned supervisors observed their lessons regularly, $61 \%$ agreed with the statement that supervisors provided written comment on lesson plans. $84 \%$ opined that supervisors provided suggestive and timely feedback to them that enhanced their teaching skills; however $10 \%$ were disagreed with this statement. $56 \%$ student-teachers said that supervisors provided them an opportunity for collaborative planning; however 38\% disagreed with this statement. Whereas, only $44 \%$ participants said that supervisors demonstrated model lessons during internship program time and again.

\section{Analysis of data collected through research tool \# 02 (Interview Schedule) Problems faced by student-teachers during Internship program}

Majority of respondents (70\%) replied that the major problem faced by the internees was to implement the lesson in the actual classroom situation. $20 \%$ respondents pointed out that classroom management was another area where student- teachers had to face problems. Some of them $(10 \%)$ stated that most of the students found it difficult to develop A.V. aid that might be helpful in achieving the pre-determined objectives of the lesson. They also pointed out that if student- teachers had developed any A.V. aids for lesson, they were unable to use them in proper way.

\section{The help, facilities and support that the collaborative schools provide to student-teachers during internship program}

All respondents (100\%) replied that they provided guidance and support to the student-teachers by observing lessons delivered by student-teachers. In addition, they also provided knowledge and information about strategies / techniques to deal with students in classroom effectively. They also provided opportunities to the internees to improve their classroom management skills by involving them in solving day-to-day problems faced by children in the school. They said that they also give them knowledge and skills about developing time-table and different schools records, because such knowledge is essential for professional teachers.

One of the principal stated that, "we facilitate the student-teachers in all possible ways such as we allowed student- teachers to use existing A.V., aids and other teaching equipments available in the school for conducting their lessons. Since we don't have sufficient teaching 
learning material in our school, students are confined to used lecture method and teacher centered pedagogy while delivering lessons." Another participant said that "I always seek out that my administrative and teaching staff offers full cooperation to student-teachers".

\section{Role of concerned University departments in guiding collaborative schools about the Internship activities}

$55 \%$ respondents replied that the concerned department provided them full support and necessary information about the implementation of the program. The department also provided them necessary documents. However, $45 \%$ respondents did not agree that the concerned department gave them full support. They were of the view that the department did not give them clear instruction about their role and responsibilities during the program. One of the respondents replied that "The concerned department does not arrange any meeting before sending the student-teachers to our school. As a result we are often unaware of tasks that we are to perform as supervisors during the program.

Changes that are observe in students teaching skills by the end of the Internship program $60 \%$ respondents stated their opinion that after completing the internship program the internees were able to design and implement lesson in a real classroom. They said that to some extent internees were also able to manage classroom and develop teaching material. $40 \%$ respondents said that the ability of student-teachers to work in a group was also enhanced. They were able to observe their peers and provided them with suggestive feedback. One of the respondents said that "I don't think that the program could bring any noticeable change in the behavior and teaching skills of the internees, because of the shortage of time. The period of this program should be extended".

\section{Recommendations to make internship more effective}

All the respondents provided valuable suggestions for the further improvement of internship and those suggestions will be discussed at the end of the study.

\section{Research Out Comes}

Following are the outcomes of the study:

1. The principals and student-teachers show positive attitude towards internship program. Majority of participants $(87 \%)$ agreed that internship program was effective and useful for them.

2. Most of the participants (68\%) agreed that this program provide them with opportunity to plan and deliver lessons. However, they also believed that this program fails to enable them to critically reflect and analyze their lessons and teaching practices.

3. The study finds that the duration of the internship program is not sufficient.

4. The supervisors observed the lessons of the student teachers on regular basis during internship program. However, they did not demonstrate model lessons so that the student teachers can observe best teaching practices of the experienced teachers. 
5. There is no unified strategy to implement internship program. As a result, various departments of Faculty of Education are dealing with internship program haphazardly. Although some departments run internship program very effectively, their best practices are not shared with other departments due to lack of communication and coordination gap.

6. Student -teachers are not provided sufficient guidelines regarding peer observation. Consequently, they fail to benefit from the valuable opportunity to learn from the best practices of their colleagues.

7. The staffs of collaborative schools and student-teachers are not required by their concerned university departments to maintain proper record of internship activities.

8. There is lack of communication between the concerned university departments and the collaborative schools before and during internship program. There are no arrangements for regular visits in the collaborative schools by the teacher educators and chairpersons of the various departments of faculty of education.

9. Student teachers are required to develop teaching material. However, they are not fully guided and trained to use such material effectively to make their lessons interesting and meaningful for learners.

10. Student- teachers are mostly confined to the use of lecture method and other similar teacher-centered pedagogy during internship program.

11. Student-teachers are provided with constructive feedback after delivering the lesson in real classroom situation, but they are not given chance to discuss their lesson plans with their supervisors before delivering the lessons.

12. The focus of internship activities is found to be on improving teaching practice of the prospective teachers. However, various other school activities such as construction of classroom tests, conducting examination, and keeping school records are less emphasized.

\section{Conclusion and Suggestions}

The analyses and interpretation of data and research outcomes clearly indicate that internship program is an effective way to give training to the student-teachers about real world of work. It give them and opportunity to integrate theory and practice, plan and deliver lessons properly, critically analyze their own and peers teaching styles and improved them in the light of feedback given by supervisors. Through this program they understand the role and responsibilities of professional teachers. Internship program also give them opportunity to understand different aspects of school program and improve their skills and abilities in teaching profession. An effective and improved internship program is required in developing student-teachers personalities as true professionals in field of education.

Keeping this point in view, following are the suggestions for the development and improvement of internship program in Faculty of Education particularly and in all institutions of teacher education generally. 


\section{Suggestions}

1. Chairperson should meet with the principals of collaborative schools and student-teachers before the internship program and give them briefing about the program. It is very beneficial for all.

2. A set of written guidelines about internship program from the concerned department should be given to the concerned student-teachers and principals of the concerned schools. So they may act according to the rules and regulations as mention in the document.

3. There should be a unified strategy to implement internship program by the Faculty of Education. In addition, communication mechanism needs to be strengthened so that the best practices can be shared.

4. Collaborative planning between supervisors and student-teachers should be encouraged. Student-teachers should be given chance to develop and discuss their lesson plans with their concerned supervisors before delivering it in classroom.

5. Student-teachers should select their lessons according to the school/college syllabus in this way there will be no loss of students.

6. The practice of "Peer observation "needs to be strengthened. Peer observation is a way to provide students with an opportunity to observer pedagogical practices of their colleagues and provide them open and constructive feedback.

7. Use of innovative and child entered pedagogy needs to be encouraged during internship program.

8. Availability of resources and teaching material in collaborative schools need to be ensured where students go for internship.

9. Supervisors should be guided to use checklist, rating scale and written analysis for observing pedagogical practices of student-teachers in real classroom.

10. After completion of the program each student-teacher should submit a reflective report about what they had learned from the internship program. Also each student and supervisor should be encouraged to give suggestions to the concerned department in writing for the future improvement of the program.

11. Refreshes courses and workshops should be offered to the staff of collaborative school to enhance the knowledge and expertise of the supervisors.

12. The duration of internship program should be extended.

13. The Chairperson of concerned department and teacher educators should pay regular visits to the place of internship. For this purpose transport facility should be provided. 
References

2012, Vol. 2, No. 1

- Creswell, J. W. (1998). Qualitative inquiry and design: Choosing from five traditions, Thousand Oaks, CA: Sage.

- Gay L.R. (1996): Educational research, Prentice-Hall, Inc. New Jersey.

- Gerald R. Adams, (1985). Understanding research methods, Longman Inc., New York.

- Ministry of Education (2009). National Education Policy, Govt. of Pakistan, 2009. 